\title{
Impacts of invasive rats on Hawaiian cave resources
}

\author{
Francis G. Howarth ${ }^{1^{*}}$ and Fred D. Stone ${ }^{2}$ \\ ${ }^{1}$ Bernice P. Bishop Museum, 1525 Bernice St. Honolulu, Hawaii 96819, USA \\ ${ }^{2}$ Hawaii Community College, Hilo, USA (Deceased)
}

\begin{abstract}
Although there are no published studies and limited data documenting damage by rodents in Hawaiian caves, our incidental observations during more than 40 years of surveying caves indicate that introduced rodents, especially the roof rat, Rattus rattus, pose significant threats to vulnerable cave resources. Caves, with their nearly constant and predictable physical environment often house important natural and cultural features including biological, paleontological, geological, climatic, mineralogical, cultural, and archaeological resources. All four invasive rodents in Hawai'i commonly nest in cave entrances and rock shelters, but only the roof rat (Rattus rattus) habitually enters caves and utilizes areas in total darkness. Skeletons and feces have been found in the deepest passages, sometimes over a kilometer from the nearest known entrance although the animals may have used nearby small, inconspicuous entrances. Their impacts include damage to rare native plants in cave entrances; predation on vulnerable cave-inhabiting species, such as Thaumatogryllus tree crickets, and native moths roosting in caves; destruction of the irreplaceable remains of the extinct terrestrial fauna; damage to organic material associated with cultural and archaeological resources, thereby obscuring the historical record of humans in the islands; introduction of unnatural nutrients into subterranean ecosystems via their bodies and feces allowing the colonization of caves by other harmful alien species; and disturbance of research sites. Furthermore, the extirpation of colonies of cave-roosting moths has impacted native birds nesting in the entrance and twilight zones.
\end{abstract}

Keywords: conservation, biospeleology, paleontology, archaeology, Rattus rattus

Received 26 December 2019; Revised 11 February 2020; Accepted 12 February 2020

Citation: Howarth F.G. and Stone F.D., 2020. Impacts of invasive rats on Hawaiian cave resources. International Journal of Speleology, 49 (1), 35-42. Tampa, FL (USA) ISSN 0392-6672 https://doi.org/10.5038/1827-806X.49.1.2301

\section{INTRODUCTION}

Caves, with their nearly constant and predictable physical environment, often protect important natural and cultural resources from degradation especially by weathering. In Hawai'i, caves contain important biological, paleontological, geological, climatic, mineralogical, cultural, and archaeological resources (Howarth \& Stone, 1982; Stone et al., 2007). Specifically, caves are home to diverse communities of highly specialized native animals adapted to live only underground (Howarth, 1991; Stone \& Howarth 2007). Caves also hold an irreplaceable historical record of the extinct terrestrial biota of the islands (James \& Olson, 1991; Burney et al., 2001; Paulay \& Starmer, 2011; Ziegler et al., 2016) as well as a record of human culture through time (Sinoto, 1992; Bollt, 2005; Burney \& Kikuchi, 2006). In addition, cave entrances often provide refuge for unique native plants and animals (DLNR, 2003).
There are no native rodents in Hawai i $i$, but four species have been introduced to the islands by humans: the Polynesian rat (Rattus exulans) was introduced to Hawai'i circa 800 years ago by the early Polynesian voyagers; the house mouse (Mus musculus) and brown rat (Rattus norvegicus) were introduced post 1778 ; i.e., shortly after western contact; and roof rat (Rattus rattus) established in the 1870s (Atkinson, 1977; Tomich,1986). All four species commonly nest in cave entrances and cavities, but only the roof rat habitually enters caves and can utilize areas in total darkness. Rattus exulans prefers open habitats in the lowlands, but it is widely distributed in the islands and also occurs in upland rain forests. It can climb trees to feed but nests on the ground. Rattus norvegicus prefers urban and lowland open habitats. It nests on the ground and rarely climbs trees. It is rare or non-existent in upland rain forests. Rattus rattus is the most plastic in the habitats used by the rodents in Hawai' $i$ and is the dominant rat in many 
habitats. It is an excellent climber and nests both on the ground and in trees (Atkinson, 1977; Stone et al., 1984; Tomich, 1986).

Although there are no published studies and limited data illustrating damage to cave resources by nonnative rats in Hawai'i, our incidental observations during more than 40 years of investigating caves indicate that introduced rodents, especially the roof rat, Rattus rattus, poses significant threats to vulnerable cave resources. Our goal here is to describe the environmental impacts of non-native rats in Hawaiian caves, including damage to rare native plants in cave entrances, predation on biological resources, destruction of the irreplaceable remains of the extinct terrestrial fauna, loss of organic material associated with cultural and archaeological resources, introduction of unnatural nutrients into subterranean ecosystems, and disturbance of research sites.

\section{METHODS}

We examined as many caves as possible under the restraints placed by the objectives that were defined under each grant or contract. Our cave surveys were conducted between 1971 and 2012 and included limestone and lava tube caves on Kaua'i and O'ahu, lava tube and piping caves on Moloka'i, and lava tube caves on Maui and Hawai'i islands. On Hawai'i island, the lava tubes surveyed ranged between sea level to 3,900 m elevation above sea level. Lava tubes are common landforms on young shield volcanoes, and range in size from a few meter-long shelters to extensive systems $50 \mathrm{~km}$ or more long and descend over 1,000 meters in elevation. (Kauahikaua et al., 2009; Richards et al., 2018).

The caves were explored by teams using standard caving and safety techniques (NSS, 2019; Wynne et al., 2019). Our research focused primarily on cave-inhabiting arthropods and their adaptations to the environment (e.g., Hoch \& Howarth, 1999; Stone \& Howarth, 2007; Wessel et al., 2013); however, the presence and condition of other resources were noted when encountered. A few caves were entered repeatedly and studied intensively for ecological research (e.g., Howarth, 1981; Howarth, 1983). We also participated in cave projects that focused on paleontology (e.g., James \& Olson, 1991; Ziegler et al., 2016), archaeology (e.g., Hammatt et al., 1978; McEldowney \& Stone, 1991; Howarth \& Stone, 1993), and management (e.g., Stone et al., 2007).

Rats and their impacts were not the primary focus of our cave inventories, but evidence was noted when recognized. Thus, our observations likely underestimate the level of damage since more severe damage was more likely to be recognized than would more cryptic impacts. Since rat occurrence in caves was not the focus of our work and preservation was often poor, voucher specimens of the bones of dead rats were not collected.

\section{RESULTS AND DISCUSSION}

During our early surveys, we could not determine whether the occasional rat skeleton found represented animals living in the caves or were accidentally in caves and became lost as victims of their wanderlust behavior. However, the frequency, types and location of rat damage observed indicated that rats were frequently entering caves for shelter, food, and water. Also, rats often found and disturbed our bait stations and pitfall traps relatively quickly, often within a day or two of their deployment, which further corroborated their ability to navigate and exploit resources in complete darkness. Importantly, the presence of fresh rat feces at the disturbed study sites confirmed that the culprits were rats.

Rodent remains found in deep cave zones were apparently all Rattus rattus. Species determination was confirmed for rats captured in snap traps set to protect our traps and baits used to sample cave animals. For other carcasses, determination was based on size of the remaining skeleton. $R$. exulans is significantly smaller than $R$. rattus; whereas $R$. norvegicus is usually considerably larger (Tomich, 1986). In addition, $R$. rattus is an excellent climber and occurs in a wider range of habitats than the other species of rats (Atkinson, 1977; Stone et al., 1984) and, therefore, is more likely to be found in caves.

Evidence of the presence of rats was noted in at least a few caves on all islands, but most observations of rat damage to cave resources were made in lava tube caves on Maui and Hawai'i islands. Specifically, rat damage was noted in five lava tube systems on Haleakala on Maui, and in many of the 100s of lava tube systems surveyed on Kîlauea, Mauna Loa, and Hualālai volcanoes on Hawai'i island. Although we collected data on rat presence or damage in a nonsystematic way, a survey of 14 lava tubes within Hawaii Volcanoes National Park (Howarth \& Stone, 2008) provides a rough approximation of the scope of the problem. The caves ranged from near sea level to $3,800 \mathrm{~m}$ in elevation. Rats and rat damage were recorded in nine caves from sea level to $1,525 \mathrm{~m}$, i.e., $64 \%$ of the total caves surveyed.

Resource damage by rats was observed from the entrance to deep within caves, sometimes more than a kilometer from the nearest known entrance -although rats would be able to use small inconspicuous entrances to gain access to these areas of the caves. The degree of damage ranged from incidental feeding to severe; that is, nearly complete destruction of the resource. For example, rat damage was noted on a wide range of cave resources including feeding on rare native plants growing in the entrance zone, preying on native cave-inhabiting arthropods, damaging archaeological and cultural materials, gnaw marks on or completely destroying paleontological deposits, and disturbing research sites. In addition, dead rats and their feces provide novel food, which may allow other non-native species to colonize the caves. These impacts are described in more detail below.

\section{Damage to rare native plants in cave entrances}

Pit-like cave entrances often provide refuge habitats for native plants since pits capture and retain moisture and nutrients beneficial to plant growth (Howarth, 1983). Equally important, pits prevent alien ungulates from entering and eating the plants (Wynne et al., 
2014). Many rare and endangered native Hawaiian plants survive in these refuge pits (USFWS, 1996; DLNR, 2003). Rodents, however, can easily enter pits and seriously damage vulnerable species. Impacts include damage by their chewing on plants (Fig. 1) and by disrupting successful reproduction especially since seeds and fruits would tend to remain within the pit (Chimera \& Drake, 2011). Several federally protected native plant species are known primarily from cave entrance pits on Hawai'i island: notably Delissea undulata (Campanulaceae) and Pleomele hawaiiensis (Asparagaceae) (USFWS, 1996; Richards et al., 2018). Rat depredation is considered a serious threat to native Hawaiian plants (USFWS, 1996). Stone (1985) lists examples of endangered plant species damaged by Rattus rattus in Hawai'i.

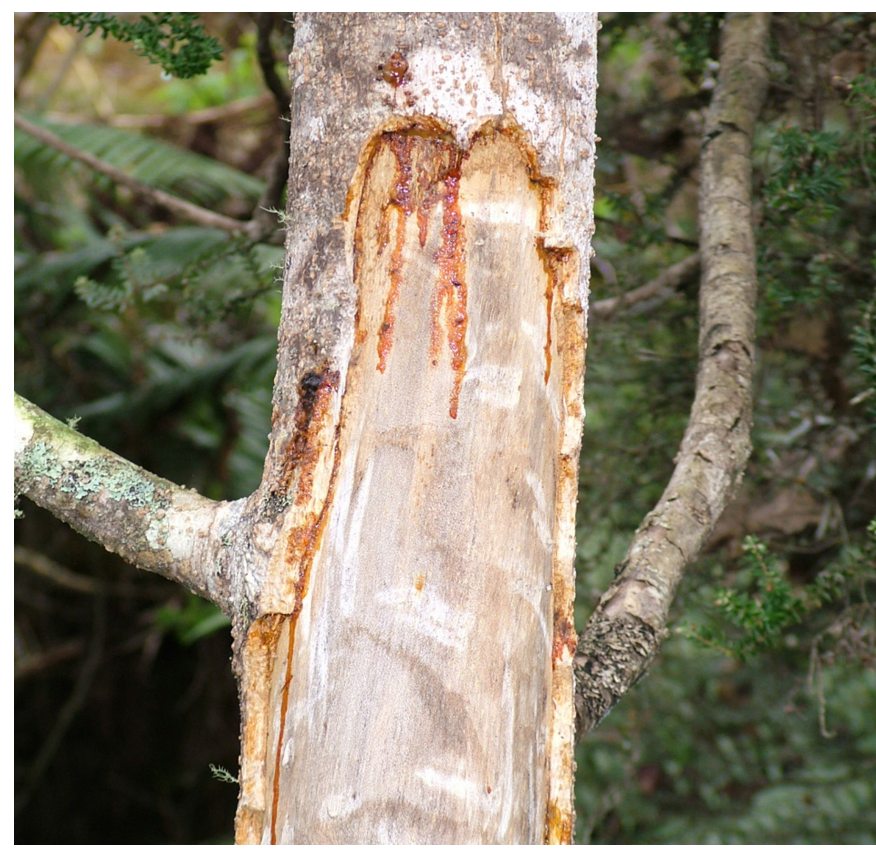

Fig. 1. Rat damage on a tree trunk of the endemic Hawaiian tree, Olapa (Cheirodendron trigynum), growing in cave entrance pit in S. Kona on Mauna Loa (Photo by D.J. Ward).

\section{Damage to biological resources in caves}

Rats are omnivores and will feed on almost any organic material they find. Their scavenging on decaying organic matter may compete with native scavengers. They feed on plant roots in caves, and thus, compete with native rhizophagous arthropods, and they prey on any cave animals they encounter. Cave-adapted arthropods may be especially vulnerable since they generally move slowly even when disturbed. For example, Thaumatogryllus (Fig. 2) cave crickets, found on Hawai'i and Maui, are large (>1 cm in length) and feign death when disturbed. This behavior would make them especially vulnerable to rat predation.

Rats are implicated in the extinction of native cave species, especially several species of large moths that once roosted in Hawaiian caves in huge colonies (Ziegler et al., 2016) much like bats and the continental cave crickets do in other regions. Two groups of native moths displayed this behavior: an underwing Hypocala velens in the family Erebidae, and cutworms in the genus Peridroma (and perhaps also the related Agrotis) in the family Noctuidae. Perkins (1913) reported that $H$. velens adults roosted

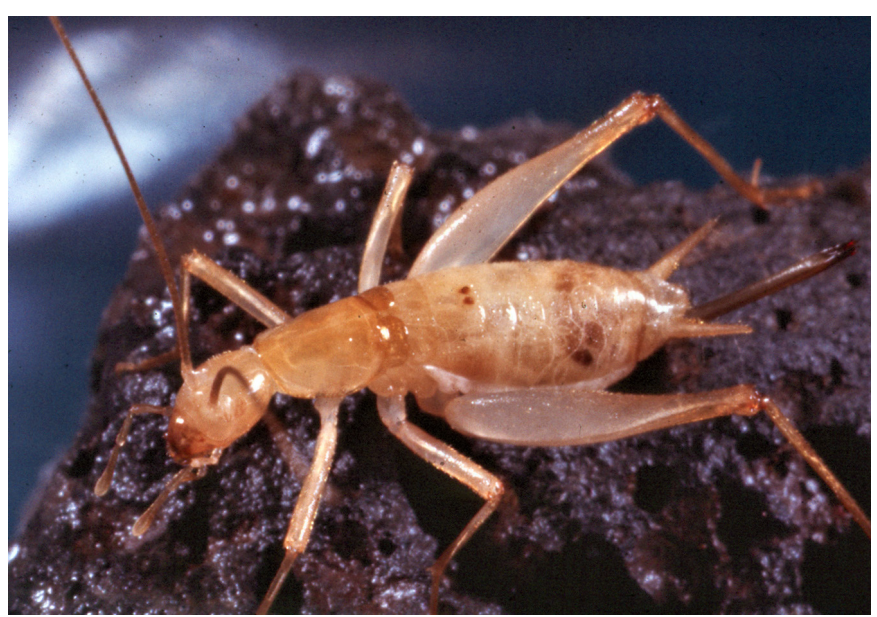

Fig. 2. Adult female of a Thaumatogryllus tree cricket from East Maui lava tube cave (Photo by W.P. Mull).

in caves and rock crevices and emerged at dusk in huge numbers. Perkins found these colonies were more common in the lowlands, but he discovered a large colony in a cave on Haleakalā, Maui, at 2,750 m elevation. We found only one cave specimen of this species during our surveys; the adult moth was roosting on the ceiling in a cave on the north slope of Mauna Loa at approximately $1,500 \mathrm{~m}$. Although now rare, the species may persist undetected in small colonies.

There are about six Peridroma species endemic to Hawai'i and 16 species of the closely related Agrotis. Several species of Peridroma once roosted in caves, and a few colonies still survive in high-elevation caves on Mauna Loa (Bonaccorso et al., 2016; Ziegler, 2016). The cold, dry rocky desert over the caves is largely inhospitable to rodents and probably has impeded their invasion. In the 1980s, we found a large colony, numbering many 1000s of individuals, of an unidentified Peridroma species roosting in a cave on the north slope of Mauna Loa at about 3,900 m. Moths leaving the cave at dusk formed a huge funnel cloud darkening the sky for 10 to 15 minutes as the moths dispersed downslope towards the saddle between Mauna Loa and Mauna Kea. This colony disappeared circa 1990. In September 2005, we found a second colony of Peridroma in a nearby cave at $3,800 \mathrm{~m}$. This colony numbered at least a few hundred adults, but an accurate count was not possible because moths were tightly clustered in crevices on the walls and ceiling (Fig. 3). A permanent pool of ice covered the floors of both caves. How cave roosting moths find their way back to their roost is unknown but may be analogous to the cave roosting Bogong moth, Agrotis infusa, in Australia (Warrant et al., 2016).

A few other colonies of moths in caves on Mauna Loa have been reported in the literature. Bunnell \& Giffin (2000) collected a dead Peridroma albiorbis in Big Red Cave, a lava tube at 3,000 m elevation on Mauna Loa. Bonaccorso et al. (2016) reported living and dead adult moths (Peridroma) in 13 lava tube caves between 2,200 and 3,600 m elevation on Mauna Loa. Incidentally, the native Hawaiian bat, Lasiurus cinereus semotus, was detected hunting around the cave entrances at dusk (Bonaccorsoet al., 2016).

In addition to bats, native birds were also associated with these moth colonies. The 'Apapane (Himatione 


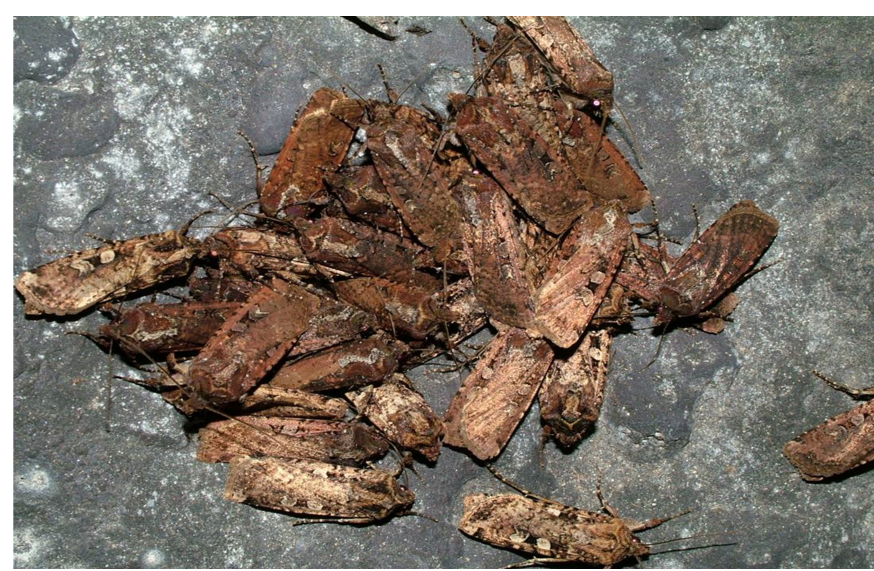

Fig. 3. A cluster of Peridroma sp. in a high-altitude cave on Mauna Loa (Photo by F.D. Stone).

sanguinea) frequently nested in the entrance and twilight zones of caves that supported moth colonies. Van Riper (1973) reported 'Apapane nesting in several high-elevation caves on Mauna Loa and Hualālai but did not note the association with moth roosts. We found dead moth remains in all the caves in which we found 'Apapane nests (Fig. 4). Finding 'Apapane nests in caves is highly unusual as this species typically nests high above the ground in trees (Van Riper, 1973). However, the easy access to adult moths as food for nestlings would have provided a strong stimulus for this behavior. Many of these nest sites in caves are no longer active indicating that the loss of moth colonies may have also decreased the distribution and abundance of 'Apapane.. In addition, the nests accessible to rats would be vulnerable to predation.

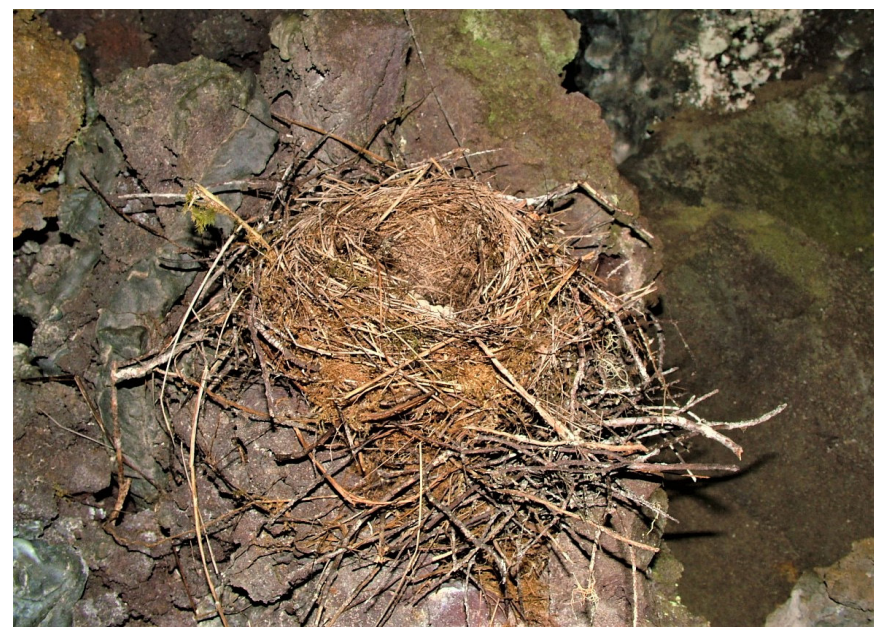

Fig. 4. 'Apapane (Himatione sanguinea) nest on shelf in the twilight zone of a of a high-altitude lava tube on Mauna Loa (Photo by F.G. Howarth).

Cave-roosting moths probably occurred on all the main islands, but except for Perkins' (1913) observations on Hypocala on Maui and lowlands generally, records for islands other than Hawai'i and Maui are lacking. Cave-roosting moths may have been an important faunal element in Maui caves in the recent past, but there is no evidence that any survive. A large colony of an unidentified Peridroma species once occupied Crystal Cave in Haleakalā Crater at 2,300 m elevation. The entrance is wide and low and leads to a single room $10-15 \mathrm{~m}$ in diameter, which is all in twilight. At the time of our survey in 1976, the dry floor was entirely covered with a several centimeter-deep layer of dust and moth fragments. No living moths were found. Rat feces were also abundant, which suggested a reason for the collapse of this colony of moths. However, populations of native cutworms have also sharply declined early to mid-20 $0^{\text {th }}$ century due to the purposeful introduction of biological control agents to control their larvae (Gagné \& Howarth, 1985). The larvae of a few of these native cutworms became pests of lawn grasses, crops, and other valuable plants, and several non-native predators and parasites were introduced in an attempt to control these pest species (Gagné \& Howarth, 1985). Thus, it may have been a combination of introduced biological control agents and rats that resulted in the substantial loss of caveroosting moth populations.

\section{Damage to paleontological resources in caves}

Caves are the premier depositories of the remains of pre-human life in the islands (Burney et al., 2001). Cave entrances often act as pitfall traps for ground dwelling animals (James \& Olson, 1991).

Plants that grow in or near entrances can become buried by sediments falling into pits during floods or collapse of the pit walls (Burney et al., 2001). Surfaceinhabiting animals occasionally enter caves, and some become disoriented and die there. Their remains provide a discontinuous record of island life over time (James \& Olson, 1991; Olson \& James, 1991; Paulay \& Starmer, 2011; Ziegler et al., 2016). So far, buried fossils are protected from direct rat damage (e.g., Burney et al., 2001), but organic and mineralized fossils exposed on the cave floor can be damaged or destroyed by rats (Fig 5). Rats may be rapidly gnawing their way through this unique record of the history of life in the islands. We have noted substantial rat damage on fossils of extinct land snails, crabs, and birds (Fig. 6).

\section{Damage to cultural and archaeological material in caves}

During pre-contact times, i.e., between the arrival of Polynesians circa AD 1200 (Wilmshurst et al., 2011) and the arrival of Europeans in 1778, the native Hawaiian peoples used caves extensively for habitation, refuge, water catchment, burials, caches, and many cultural and ceremonial purposes (Martin, 1992; Sinoto, 1992;

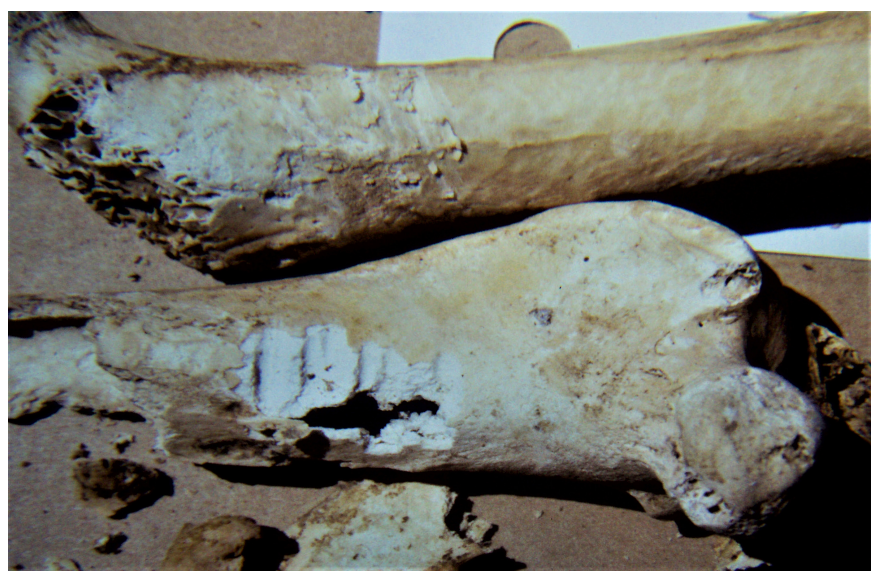

Fig. 5. Close-up of damage by rats on leg bones of an extinct moa-nalo, Ptaiochen pau (a large flightless goose-like duck), in a lava tube in Kipahulu Valley, Maui. (Photo by F.G. Howarth). 

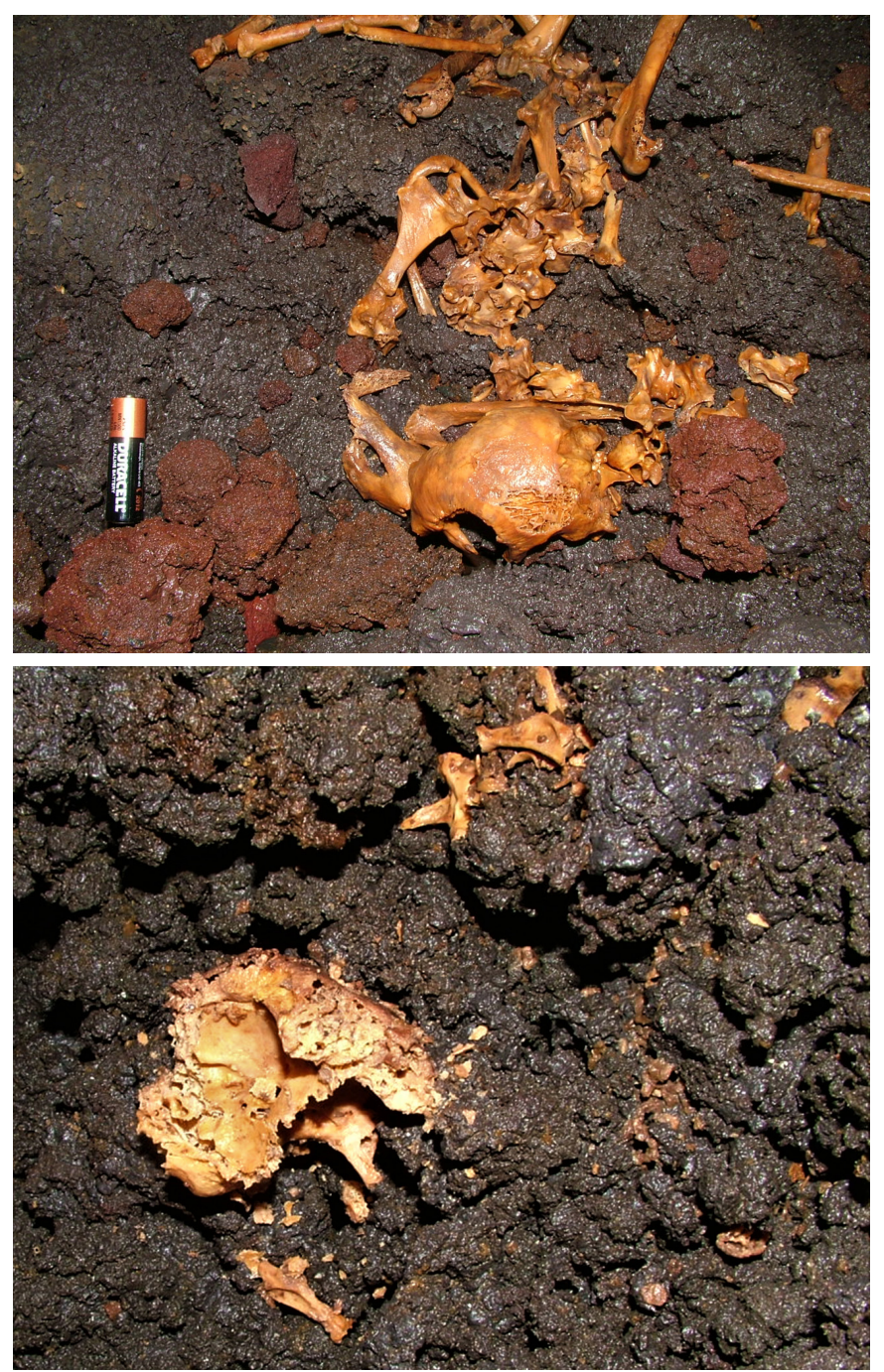

Fig. 6. Two photographs showing range of damage done by rats on bones of an extinct Hawaiian goose in a lava tube in S. Kona on Hawaii $\mathrm{i}$ Island: (Top) moderate damage; (Bottom) severe damage making identification and taphonomy impossible (Photos by D.J. Ward).

Bollt, 2005; Esh et al., 2008). Organic and mineral artifacts left in caves by Hawaiians are susceptible to the depredations by rats. Once destroyed the evidence of human use of caves is lost, and the historical record of humans in the islands is obscured. For example, Hawaiians commonly excavated small water catchment basins into the cave floor beneath drips (Martin, 1992) (Fig 7). Cultural material left at these basins reveal how and when they were made and used (Esh et al., 2008). Rats can damage or destroy much of this evidence thereby erasing part of the cultural history of Hawai'i. Rat damage at water catchment sites includes destruction of marine shells used as dippers, remains of torches and other organic debris associated with the basin, and calabash gourds (Fig. 8) used to collect and transport water.

\section{Introduction of unnatural nutrients into caves}

The roof rat ( $R$. rattus) is pervasively invading into the deepest parts of caves in search of food, water, or from wanderlust. Feces (Fig. 9) and diaspora carried into caves by rats, along with their dead bodies, introduce unnatural foods into the subterranean ecosystem that may allow other harmful alien species to colonize caves. Populations of non-native cavernicoles that may benefit from the presence of rats include a few

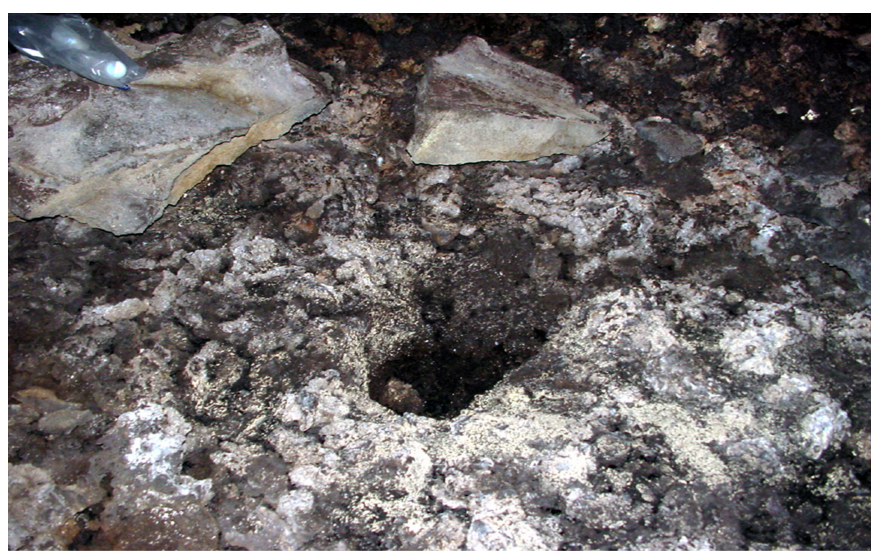

Fig. 7. Small water catchment excavated into cave floor in a lava tube in N. Kona on Hawai'i Island. The white color is ash and mineral deposits from torches. The rocks, or 'manuports,' are props for supporting a calabash gourd or torch (Photo by D.J. Preston).

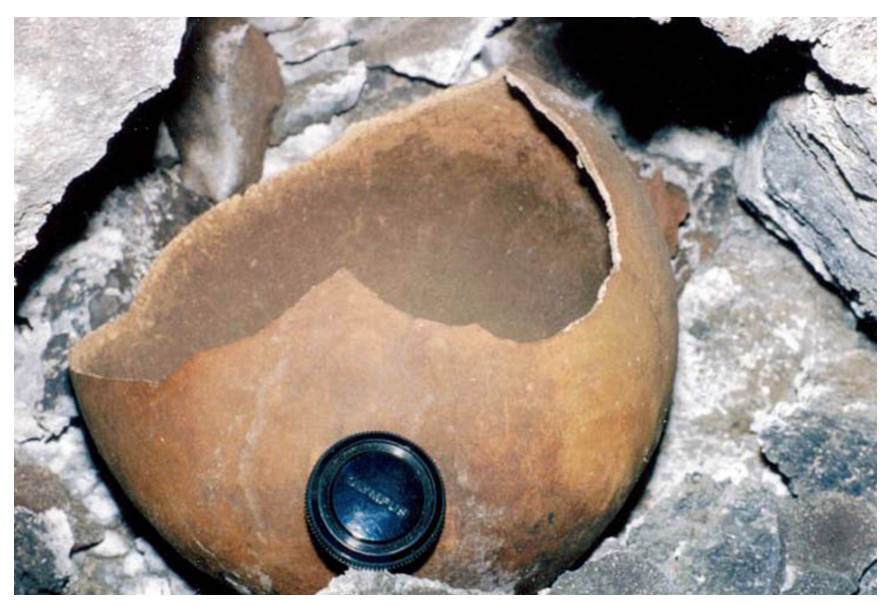

Fig. 8. A calabash gourd, which has been heavily damaged by rat(s), present at a cultural site in a lava tube in S. Kona on Hawai'i Island. The black lens cap denotes scale (Photo by F.D. Stone).

species each of isopods, springtails, beetles, and flies. Among the flies, non-native scuttle flies (Phoridae) commonly are attracted to rotting meat and thus suspected of feeding on rat carcasses; however, these small flies rarely leave any trace on skeletons.

Many (uncounted but perhaps 5\%) rat skeletons in caves are associated with large accumulations of calyptrate fly puparia. Curiously, all that have been identified belong to the muscid fly, Synthesiomyia nudiseta. Apparently, S. nudiseta can out-compete the other approximately 15 species of large non-native necrophagous flies recorded in Hawai $i$, and complete development in total darkness. In arthropod surveys in surface habitats, $S$. nudiseta is often present but is not as common as many related species (Howarth et al., 2012).

A few native cave species, such as some collembola, isopods, millipedes, and flies, can also feed on this imported material. Steffan (1973) described a native black fungus gnat, Phytosciara (Prosciara) vulcanata, from adults reared from fungus covered rat feces.

\section{Disturbance of research sites}

The speed and frequency at which rats find and disturb bait stations and pitfall traps in caves indicate that they are frequent visitors and welladapted to navigate complex mazes in total darkness. Rats also occasionally disturb or damage study 


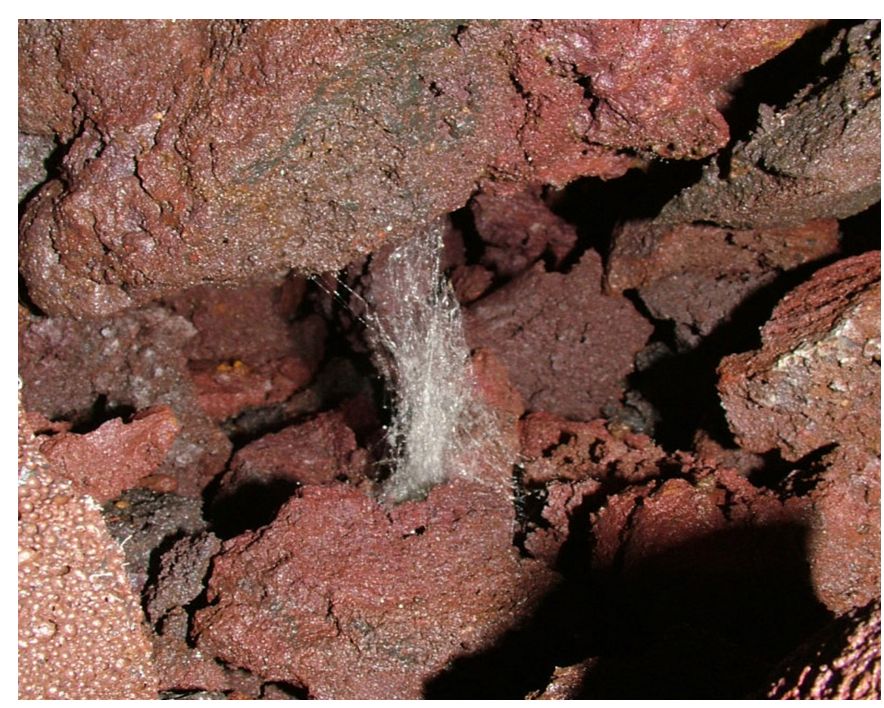

Fig. 9. Fungus covered rat feces in a lava tube in S. Kona on Hawai'i Island (Photo by D.J. Ward).

sites and equipment such as atmometers and hygrothermographs. Their presence has required us to protect sampling stations from their depredations by placing sampling material on high ledges or under rocks; that is, out of reach of rats. When possible, we also set snap traps, which both lowers the risk they represent, while also providing additional bait for our sampling (Fig. 10). We have not yet found evidence of rats nesting in deep caves and conclude that rats probably are not residents within caves but visitors.

\section{Conservation implications}

We have documented examples of real and potential threats caused by invasive rats on cave resources in Hawai'i. However, since our observations were incidental and not quantified, the true severity of these threats is unknown. We, therefore, encourage researches and other persons studying caves to be aware of the problem and accurately record evidence of rat activity and related damage, not only in Hawai'i but wherever invasive rats occur. With better documentation, it will be possible to perform specific research programs to quantify rat impacts and to develop appropriate monitoring and mitigation programs. Several public and private agencies in Hawai'i are supporting research on protocols to effectively control rats in sensitive habitats [e.g., Department of Land and Natural Resources (DLNR), National Park Service, and The Nature Conservancy]. Caves should be included in that effort.

In a few instances where we noted rat damage was severe and on-going, we made recommendations to control rat populations in and around the affected cave or to fully inventory and/or retrieve the resource. However, many of the examples we recorded are so widely scattered in different caves, that, with few exceptions, it is not feasible at present to develop programs to address the issue.

One issue that should be addressed currently is the impact of rats on populations of cave-roosting moths. Currently, most large colonies of these moths occur outside the range of invasive rodents; that is, in lava tubes on sparsely vegetated lava flows at high elevation. The cold environment with few food

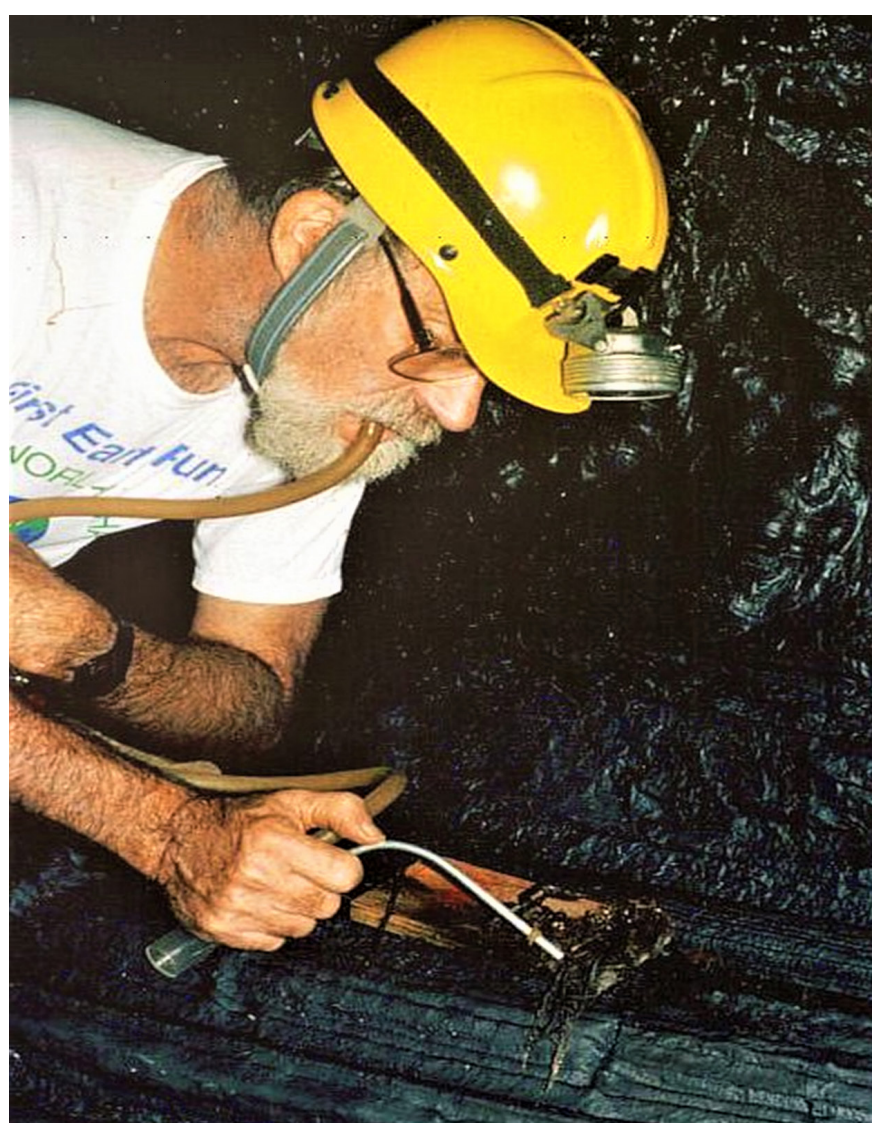

Fig. 10. F.D. Stone collecting arthropods from a rat carcass killed by a snap trap in a lava tube on the East Rift on Kîlauea, Hawai'i Island (Photo by F.G. Howarth).

resources for rodents has slowed their dispersal into this habitat. However, they would be able to follow human hiking trails and roads, especially if humans are discarding trash along the trail. Trail mixes of grains, nuts, and dried fruits are excellent baits for rats. High altitude trails should be monitored for the presence of rats and the discarded organic material removed. In the early 1990 s, resource managers at Hawaii Volcanoes National Park rerouted a summit trail on Mauna Loa to bypass a cave with a known population of moths in hopes of preventing rats from finding the cave. Additionally, caves harboring moth colonies or nesting birds should be monitored regularly, and if rats are suspected, an appropriate control program should be initiated before the colony collapses.

Problems posed by rodents outside of Hawai'i were beyond the scope of the present study although such impacts certainly occur. Rattus rattus is a cosmopolitan pest widely recognized as one of the most damaging invasive species worldwide (Global Invasive Species Database, 2020). Our observations in Hawaiian caves indicate that rats pose similar problems in other regions of the world. We encourage researchers to record their observations of rodent activity in caves. Caves in continental areas often harbor native vertebrates, including rodents [e.g., Neotoma rats in North American caves (Dunning \& Payne, 1979; Clark et al., 1994)], which may also disturb cave resources. For example, Clark et al. (1994) provide circumstantial evidence of the native wood rat, Neotoma floridana preying on endangered Ozark big-eared bats (Corynorhinus townsendii ingens) roosting in Oklahoma caves. 


\section{ACKNOWLEDGMENTS}

We sincerely thank the many colleagues and students who assisted us in fieldwork and laboratory over the years. D.J. Ward, D.J. Preston, and the late W.P. Mull kindly provided photographs. We also thank J.J. Wynne and an anonymous reviewer for many helpful comments that strengthened the paper. Support for fieldwork was provided by several contracts and grants from state and federal agencies and private entities including the Hawai'i Department of Land and Natural Resources, the Hawai'i Bishop Research Institute, the National Park Service, the US Department of the Interior, the US Army Legacy Program, the National Science Foundation (DEB 75-23106, DEB-7904760, BSR 85-15183), and the Nature Conservancy.

\section{REFERENCES}

Atkinson I.A.E., 1977 - A reassessment of factors, particularly Rattus rattus $L$., that influenced the decline of endemic forest birds in the Hawaiian Islands. Pacific Science, 31: 109-133.

Bollt R., 2005 - Tricks, traps, and tunnels: a study of refuge caves of Hawai'i Island. Hawaiian Archaeology, 10: 96-114.

Bonaccorso F.J., Montoya-Aiona K., Pinzari C.A. \& Todd C.M., 2016 - Winter distribution, altitudinal migration, and use of high elevation caves by the endangered Hawaiian hoary bat, Lasiurus cinereus semotus. Hawai'i Cooperative Studies Unit University of Hawai`i at Hilo. Technical Report HCSU-068. 24 p.

Bunnell D. \& Giffin J., 2000 - Bats in Big Red Cave, Big Island of Hawaii. National Speleological Society News, 58: 122.

Burney D.A., James H.F., Burney L.P., Olson S.L., Kikuchi W., Wagner W.L., Berta M., McCloskey D., Kikuchi D., Grady F.V., Gage R. \& Nishek R., 2001 - Fossil evidence for a diverse biota from Kaua'i and its transformation since human arrival. Ecological Monographs, 71: 615-641.

https://doi.org/10.1890/0012-9615(2001)071 [0615:FEFADB]2.0.CO;2

Burney D.A. \& Kikuchi W., 2006 - A millennium of human activity at Makauwahi Cave, Māhā'ulepū, Kaua'i. Human Ecology, 34: 219-237.

https://doi.org/10.1007/s10745-006-9015-3

Chimera C.G. \& Drake D.R., 2011 - Could poor seed dispersal contribute to predation by introduced rodents in a Hawaiian dry forest? Biological Invasions, 13: 1029-1042.

https://doi.org/10.1007/s10530-010-9887-4

Clark B.K., Clark B.S. \& Leslie D.M. Jr., 1994 - Use of caves by Eastern Woodrats (Neotoma floridana) in relation to bat populations, internal cave characteristics and surface habitats. The American Midland Naturalist, 131 (2): 359-364.

https://doi.org/10.2307/2426261

DLNR, 2003 - Management Plan for the Ahupua'a of Pu'u Wa'awa' $a$ and the Makai Lands of Pu'u Anahulu. State of Hawaii, Department of Land and Natural Resources, Division of Forestry and Wildlife \& Division of State Parks, 86 p.

Dunning D.C. \& Payne L.N., 1979 - Orientation in cavedwelling wood rats. Behavioral Ecology and Sociobiology, 6: 1-9. https://doi.org/10.1007/BF00293239
Esh K., Bell M., Simonson M., Shideler D. \& Hammatt H.H., 2008 - Archaeological inventory survey of a 363.106-acre parcel within portions of Kaloko Ahupua'a North Kona District, Hawai'i Island TMK: [3] 7-3-009:028. Prepared for Stanford Carr Development LLC., 294 p.

Gagné W.C. \& Howarth F.G., 1985 - Conservation status of endemic Hawaiian Lepidoptera. In: Heath J. (Ed.), Proceedings $3^{\text {rd }}$ Congress European Lepidopterology, Cambridge. 1982. Karlsruhe: Society European Lepidopterology, p. 74-84.

Global Invasive Species Database. 2020. Downloaded from http://www.iucngisd.org/gisd/100 worst.php on 02-02-2020 [accessed February, 2020].

Hammatt H.H., Howarth F.G., Miura M.T. \& TomonariTuggle M.J., 1978 - Archaeological and biological survey of the proposed Kiahuna Golf village area: Koloa, Kona, Kaua'i Island, Hawaii. Moana Corp, Archaeological Research Center Hawaii, Environment Impact Study Corporation, $464 \mathrm{p}$.

Hoch H. \& Howarth F.G., 1999 - Multiple cave invasions by species of the planthopper genus Oliarus in Hawaii (Homoptera: Fulgoroidea: Cixiidae). Zoological Journal of the Linnean. Society, 127: 453-475. https://doi.org/10.1111/j.1096-3642.1999.tb01381.x

Howarth F.G., 1981 - Community structure and niche differentiation in Hawaiian lava tubes. Chapter 7. In: Mueller-Dombois D., Bridges K.W. \& Carson H.L. (Ed.) Island ecosystems: Biological organization in selected Hawaiian communities. US/IBP Synthesis Series. Vol. 15. Hutchinson Ross Publishing Co., PA. p. 318-336.

Howarth F.G., 1983 - Bioclimatic and geologic factors governing the evolution and distribution of Hawaiian cave insects. Entomologica Generalis, 8: 17-26.

Howarth F.G., 1991 - Hawaiian Cave Faunas: macroevolution on young islands. In: Dudley E.C. (Ed.), The unity of evolutionary biology, vol. 1. Dioscorides Press, Portland, p. 285-295.

Howarth F.G., Preston D.J. \& Pyle R., 2012 - Surveying for terrestrial arthropods (insects and relatives) occurring within the Kahului Airport environs, Maui, Hawai'i: Synthesis report. Submitted to EKNA Services, Inc., 615 Piikoi Street, Suite 300, Honolulu, Hawaii 96814, and the State of Hawaii, Department of Transportation, Airports Division, 215 p.

Howarth F.G. \& Stone F.D., 1982 - The Conservation of Hawaii's Cave Resources. Proceedings of the $4^{\text {th }}$ Conference in Natural Science, Hawaii Volcanoes National Park, Hawai'i Cooperative Studies Unit University of Hawai'i at Mānoa, Department of Botany U.H. Mānoa, Honolulu, Hawai‘i, p. 94-99.

Howarth F.G. \& Stone F.D., 1993 - Reconnaissance survey of the caves of the coastal lands of the Kiholo Bay Area, Island of Hawaii. Bishop Museum Report to the Division of State Parks, DLNR, p. 1-40.

Howarth F.G. \& Stone F.D., 2008 - Biological inventory and assessment of selected caves at Hawaii Volcanoes National Park. Confidential draft report submitted to Resources Management Division, Hawaii Volcanoes National Park.

James H.F. \& Olson S.L., 1991 - Descriptions of 32 new species of birds from the Hawaiian Islands: part II. Passeriformes. Ornithological Monographs, 46: 1-88. https://doi.org/10.2307/40166713

Kauahikaua J., Howarth F.G. \& Hon K., 2009 - Lava tubes. In: Gillespie R. \& Clague D. (Ed.), Encyclopedia of islands. University California Press, Berkeley, p. 544-549.

Martin J.F., 1992 - Native Hawaiian water collection systems in lava tubes (caves) and fault cracks. In: Rea G.T. (Ed.), Proceedings of the $6^{\text {th }}$ International Symposium on Vulcanspeleology, Hilo, Hawaii 1991, p. $10-14$. 
McEldowney H. \& Stone F.D., 1991 - Survey of lava tubes in the former Puna Forest Reserve and on adjacent state of Hawaii lands. Prepared for: State Historic Preservation Division, Division of Water Resource Management, Department of Land and Natural Resource, State of Hawaii, p. 56. https://doi.org/10.2172/882390

NSS, 2019 - Safety \& techniques - Safety. National Speleological Society. https://caves.org/safety/safety. shtml [Accessed December 2019].

Olson S.L \& James H.F., 1991 - Descriptions of 32 new species of birds from the Hawaiian Islands: part I. NonPasseriformes. Ornithological Monographs, 45: 1-88. https://doi.org/10.2307/40166794

Paulay G. \& Starmer J., 2011 - Evolution, insular restriction, and extinction of oceanic land crabs, exemplified by the loss of an endemic Geograpsus in the Hawaiian Islands. PLoS ONE 6 (5): e19916. https://doi.org/10.1371/journal.pone.0019916

Perkins R.C.L., 1913 - Introduction to Fauna Hawaiiensis. In: Sharp D. (Ed.), Vol. 1, xv-ccxxvii. Cambridge University Press, Cambridge.

Richards B., Vesely C. \& Bosted P., 2018 - Delissea Cave System in Hawaii. Abstract. In: Proceedings of the $18^{\text {th }}$ Symposium on Vulcanospeleology, 21-27 July 2018, Lava Beds National Monument, California.

Sinoto Y.H., 1992 - Hawaiian use of lava tube caves and shelters. In: Rea G.T. (Ed.), Proceedings of the $6^{\text {th }}$ International Symposium on Vulcanspeleology. Hilo, HI 1991, p. 3-6.

Steffan W.A., 1973 - Notes on Hawaiian Sciaridae (Diptera) and descriptions of two new species. Pacific Insects, 15: 353-361.

Stone C.P., 1985 - Alien animals in Hawai'i's native ecosystems: toward controlling the adverse effects of introduced vertebrates. In: C.P. Stone \& Scott J.M. (Eds.), Hawai'i's terrestrial ecosystems: Protection and management. University of Hawaii Press, Honolulu, p. 251-297.

Stone C.P., Banko P.C., Higashino P.K. \& Howarth F.G., 1984 - Interrelationships of alien and native plants and animals in Kipahulu Valley, Haleakala National Park: A preliminary report. In: Smith C.W. (Ed.), Proceedings of the $5^{\text {th }}$ Conference in the Natural Sciences, Hawaii Volcanoes National Park, 5-7 June 1984. Coop. National Park Resources Studies Unit, UH, Honolulu, p. 91-105.

Stone F.D. \& Howarth F.G., 2007 - Hawaiian cave biology: Status of conservation and management. In: Rea
T. (Ed.), 2005 National Cave and Karst Management Symposium, p. 21-26.

Stone F.D., Howarth F.G. \& Nakamura J.M., 2007 Lava cave management in Hawai'i Volcanoes National Park. In: Rea T. (Ed.), 2005 National Cave and Karst Management Symposium, p. 155-163.

Tomich P.Q., 1986 - Mammals in Hawaii: A synopsis and notational bibliography ( $2^{\text {nd }}$ Ed.). Bishop Museum Press, Honolulu, Hawaii, 375 p.

United States Fish and Wildlife Service (USFWS), 1996 Final listing rules. Endangered Species Bulletin, 21: 24-26.

Van Riper C., 1973 - The nesting of the 'apapane in lava caves on the island of Hawai'i. Wilson Bulletin, 85: 238-240.

Warrant E., Frost B., Green K., Mouritsen H., Dreyer D., Adden A., Brauburger K. \& Heinze S., 2016 The Australian Bogong Moth Agrotis infusa: A longdistance nocturnal navigator. Frontiers in Behavioral Neuroscience, 10 (77): 1-17.

https://doi.org/10.3389/fnbeh.2016.00077

Wessel A., Hoch H., Asche M., von Rintelen T., Stelbrink B., Heck V., Stone F.D. \& Howarth F.G., 2013 - Founder effects initiated rapid species radiation in Hawaiian cave planthoppers. Proceedings National Academy of Sciences, 110 (23): 9391-9396.

https://doi.org/10.1073/pnas.1301657110

Wilmshurst J.M., Hunt T.L., Lipo C.P. \& Anderson A.J., 2011 - High-precision radiocarbon dating shows recent and rapid initial human colonization of East Polynesia. Proceedings of the National Academy of Sciences, 108 (5): 1815-1820.

https://doi.org/10.1073/pnas.1015876108

Wynne J.J., Bernard E.C., Soto-Adames F., Taiti S., Mockford E.L., Howarth F.G., Sommer S., Horrocks M., Pakarati L. \& Pakarati-Hotus V., 2014 - Disturbance relicts in a rapidly changing world: the Rapa Nui (Easter Island) factor. BioScience, 64: 711-718.

https://doi.org/10.1093/biosci/biu090

Wynne J.J., Howarth F.G., Sommer S. \& Dickson B.G., 2019 - Fifty years of cave arthropod sampling: techniques and best practices. International Journal of Speleology, 48 (1): 33-48.

https://doi.org/10.5038/1827-806X.48.1.2231

Ziegler A.C., Howarth F.G. \& Simmons N.B., 2016 - A second endemic land mammal for the Hawaiian Islands: a new genus and species of fossil bat (Chiroptera: Vespertilionidae). American Museum Novitates, 2016: 1-52. https://doi.org/10.1206/3854.1 